DOI https://doi.org/10.18551/rjoas.2017-02.23

\title{
DETERMINANTS OF RURAL FARMERS' DECISION TO ADAPT TO CLIMATE CHANGE IN GHANA
}

\author{
Acquah Sarah, PhD Student \\ New Mexico State University, Las Cruces, USA \\ E-mail: awiaso@gmail.com
}

\author{
Kendie Stephen \\ College of Humanities and Legal Studies, University of Cape Coast, Ghana \\ E-mail: stephenkendie@gmail.com
}

Agyenim Joseph Boateng

Institute for Development Studies, University of Cape Coast, Ghana

E-mail: jbagyenim@gmail.com

\begin{abstract}
Increased variability in temperature and precipitation aggravate crop farmers' productivity especially rural farmers in developing countries where smallholder agriculture is a major source of livelihood. In an era of climate change, farm level adaptation strategy is crucial to combating food insecurity and lost farm income. To guide policy in this direction, it is important to understand the determinants of farmers' decision to adapt to climate change. Data was collected from 200 farmers randomly selected from six farming zones in the Shama district of Ghana. Binary logistic and semi-log regression models were used to estimate the socio-economic and institutional factors that determine farmers' decision to adapt to climate change, their access to credit and the size of agricultural land in production. The results revealed relevant social-economic and institutional factors that significantly determine farmers' decision to adapt to climate change, their access to agricultural loans as well as agricultural land in production. Policy decisions on farm level adaptation may focus on the relevant socio-economic and institutional factors to help farmers develop resilience to a changing climate.
\end{abstract}

\section{KEY WORDS}

Climate change, adaptation, food security, socio-economic factors.

Substantial changes in global climate are already being experienced in the form of increased drought, more intense storms, floods and other environmental stress. Trenberth, Fasullo, \& Shepherd (2015) revealed that the changing climate is actually a new normal. Therefore, it is unlikely for some farmers who are currently experiencing critical drought periods to have wet periods in the future based on historical trends. In view of this, farmers need to consider adaptation and mitigation strategies to adjust to the changing climate and possible new normal.

Variability in rainfall and other climatic factors greatly affect cropping patterns, crop yield and food security efforts. Countries that depend heavily of natural precipitation may be severely affected by climate change. The absence of appropriate measures to reduce the negative impact of climate change can potentially affect the developments aspirations of many countries especially developing countries battling with adverse impacts of high population growth and the endemic poverty.

Manifestations of climate change in Ghana. In Ghana, the impacts of climate change scenarios could potentially threaten the socio-economic well-being of many people. Estimate from nationally observed climate data coupled with IPCC climate scenarios suggest a continuous increase in temperature and decrease in rainfall. On average temperature in Ghana is expected to rise by $0.6^{\circ} \mathrm{C}, 2.0^{\circ} \mathrm{C}$ and $3.9^{\circ} \mathrm{C}$ in 2020,2050 and 2080 respectively (United Nations Framework Convention on Climate Change, 2011). On the other hand, 
rainfall is expected to decrease by an average estimate of $2.8 \%, 10.9 \%$ and $18.6 \%$ for the year 2020, 2050 and 2080 respectively. Furthermore, historical data show a sea-level rise of $2.1 \mathrm{~mm}$ per year for the last 30 years (Masters, Baker, \& Flood, 2010). The expected changes may have serious implications for the agricultural sector and also human settlement of the coastal areas of Ghana.

The agricultural sector in Ghana account for nearly one-quarter of the country's GDP and employs more than half of the workforce which is largely small landholders (over $85 \%$ are 2 ha or less in size) (Ghana Statistical Service, 2014). Food production in the country mainly depends on precipitation and other weather patterns. Variability in rainfall patterns will impact on the quality and quantity of food produced. Cocoa is the principal cash crop grown on $40 \%$ of all cultivated land in Ghana. Millet is a staple crop in the grown in the northern regions while maize (corn) and rice are widely grown and consumed throughout the country. The above mentioned cereals are relatively vulnerable to climate change yet very important to the Ghanaian people in terms of food security. Ghana's increasing temperatures may result in low cereal yields due to a limited growing period and high water requirements.

The spin-off effects on the rest of the economy can lead to devastating consequences in the form of declining agricultural productivity, reduced farm income, increased food prices and lost livelihoods among others. It is highly likely that imports and exports of commodity crops will be affected and this is particularly important for cocoa, Ghana's principal cash crop. Any change in crops yield and distribution will affect livelihoods, particularly if yields decrease and the main crops in the region become marginal or impossible to grow due to climate change.

Previous works. Efforts to help address the problem of climate change are ongoing. Climate change initiatives in Ghana include the case of Climate Smart Landscape (CSL) planning approach which focuses on climate-cocoa partnership between Rainforest alliance and Olam. The objective of the partnership is to develop local livelihoods by promoting climate smart cocoa cultivation(Salvini, G., Ligtenberg, A., van Paassen, A., Bregt, A.K., Avitabile, V., \& Herold, 2016).

Other climate change initiatives such as the Netherlands Climate Change Studies Assistance Program (NCCSAP), Climate Change and Development - Adapting by reducing vulnerability (CC-DARE) and Africa Adaptation Program (AAP) all helped to reduce the risk and vulnerabilities brought on by climatic changes. Though climate change is a physical process involving changes in climatic variables, it is influenced by social processes that relate to the way society evolves through time. Climate change will impact on social, economic, and environmental systems and shape the prospects for food, water, and health security (Adger, 1999; Christensen et al. 2007).

Although climate change is a physical process it can relate directly related to the livelihood systems of any society. Dumenu (2014) examined the vulnerability of rural communities in Ghana to climate change. His results show that socio-economic factors influencing vulnerability include household size, access to climate change information, climate sensitive occupation and diversification of income. Yet to inform policy, these results are lacking because the author failed to measure the effect of the socio-economic factors that influence climate change using rigorous statistical methods. The capacity to mitigate and adapt to climate change impacts depends on proactive measures to address the challenges climate change brings in its wake.

Gaps. Regardless of the ongoing climate change initiatives in Ghana, most of the programs are largely at the national level and does not target specific sectors such as the agricultural sector. Also previous climate change related researches are limited in scope with respect to the areas they covered and lack rigorous statistical analysis. No statistical investigations have been undertaken to understand the determinant of farmers' decision to adapt to climate change in the study area.

The need for rural farmers to adapt to climate change is relevant for food security. Understanding the impacts of climate change on farmers' productivity is crucial for the choice of adaptation strategies and mitigation policies. To address the growing challenges of climate, change that farmers face, it is important to understand the determinants of farmers' 
decision to adapt to climate change. The objective of the study was to examine farmers' perceptions of climate change, their choice of adaptation strategies in response to climate change and the barriers they encounter. It also estimated the socio-economic and institutional factors that influence farmers' productivity and the decision to adapt to climate change.

\section{MATERIALS AND METHODS OF RESEARCH}

Study area. Shama district is one of the 22 districts in the Western Region of Ghana. The district was recently carved out of the former Shama Ahanta East Metropolitan Assembly. Shama district has a population of 81,966 based on projections from 2010 Population and Housing Census (Ghana Statistical Service, 2014). The district falls within coastal savannah agro-ecological classification and experiences two rainy seasons. The people are predominantly farmers with a total of about one third of the adult population in the district engaged in agriculture (Ghana Statistical Service, 2014). Farmers rely on traditional methods of farming using simple farm tools such as hoe, cutlass and depend on rainfall for cropping.

Data. The study population includes all farmers within the Shama district which was estimated to be 7100 (Ministry of Food and Agriculture, MOFA, Shama district office, 2012). Shama district is divided into six farming zones. Two farming communities were selected randomly from each farming zone. The lists of farmers in the selected communities were obtained with the help of Agricultural Extension Officers responsible for the area.

Farmers were interviewed to investigate whether they have noticed long-term climate changes. The sample size of the study was determined statistically using the equation specified below. Sample proportions based on the six farming zones were calculated as shown in Table 1. Data was collected on farmers' socio-economic characteristics, farmers' perception of climate change, farmers' adaptation measures in response to climate change and barriers to adaptation measures.

$$
n=\hat{p} * \hat{q}\left[\frac{Z \alpha / 2}{d}\right]^{2}
$$

Where: $\mathrm{n}=$ desired sample size; $\mathrm{z}=$ the critical $\mathrm{z}$ value $=1.96 ; \mathrm{p}=$ the estimated proportion of farmers in the district $=0.70$ (MOFA, Shama district); $q=1-0.70=0.30 ; d=$ the allowable error $5 \%=0.05$.

Table 1 - Sample size estimation

\begin{tabular}{llll}
\hline Farming Zones & Population & Sample & Calculated sample proportions \\
\hline Shama south & 1500 & 68 & 42 \\
Shama north & 1000 & 45 & 28 \\
Asokor Asaaman & 1200 & 55 & 34 \\
Assin & 1800 & 82 & 51 \\
Beposo & 700 & 32 & 20 \\
Dunkwa & 900 & 41 & 25 \\
Total & 7100 & 323 & 200 \\
\hline
\end{tabular}

Source: MOFA, Shama district office (2012).

Methods. Both Ordinary Least Squares estimation and binary logit model were used in the data analysis. The assumptions underlying Ordinary Least Squares estimation was tested to ensure none is violated and that the model is predicting well. Binary logit is also used to determine the factors that influence the decision to adapt to climate change.

Logistic regression makes no assumption of the distribution of the independent variables. They do not have to be normally distributed, linearly related or of equal variance within each group (Agresti, 1996). The logit model as applied to this research follows a 
binomial distribution. The decision variable $Y_{i}$ is a binary response variable that can take on the value of 1 or 0 . Mathematically expressed as shown below

$$
Y_{i}=\left\{\begin{array}{l}
1 \text { decision to adapt to climate change } \\
0 \text { otherwise }
\end{array}\right.
$$

Since there exist 200 independent observations, $\mathrm{y}_{1}, \ldots, \mathrm{y}_{200}$, and the $\mathrm{i}$-th observation is treated a $S$ a random variable $Y_{i}$ then $Y_{i}$ follows a binomial distribution specified as shown below where $n_{i}$ is the binomial denominator and $\pi_{i}$ is the probability.

$$
Y_{i} \sim B\left(n_{i}, \pi_{i}\right)
$$

Following that the probabilities are expressed as a linear function of the observed vector of covariates, $X_{i}$.

$$
\text { Thus } \pi_{i}=X_{i}^{\prime} \beta
$$

Where: $X_{i} \ldots$ Observed vector of covariates; $\beta$.... Vector of regression coefficients.

Assuming that the Logit of the underlying probability is a linear function of the predictions gives:

$$
\operatorname{logit}\left(\pi_{i}\right)=X_{i}^{\prime} \beta
$$

Now the odds ratio of the i-th respondent is determined as follows:

$$
\frac{\pi_{i}}{\left(1-\pi_{i}\right)}=\exp \left\{X_{i}^{\prime} \beta\right\}
$$

Solving for the probabilities of respondent's decision in (4) takes the following steps.

$$
\begin{aligned}
& \pi_{i}=\exp \left\{X_{i}^{\prime} \beta\right\}\left[\left(1-\pi_{i}\right)\right. \\
& \pi_{i}=\exp \left\{X_{i}^{\prime} \beta\right\}-\pi_{i} \exp \left\{X_{i}^{\prime} \beta\right\} \\
& \pi_{i}+\pi_{i} \exp \left\{X_{i}^{\prime} \beta\right\}=\exp \left\{X_{i}^{\prime} \beta\right\} \\
& \pi_{i}\left(1+\exp \left\{X_{i}^{\prime} \beta\right\}\right)=\exp \left\{X_{i}^{\prime} \beta\right\} \\
& \pi_{i}=\frac{\exp \left\{X_{i}^{\prime} \beta\right\}}{\left[1+\exp \left\{X_{i}^{\prime} \beta\right\}\right]}
\end{aligned}
$$

\begin{tabular}{|c|c|c|}
\hline Variable Name & Interpretation & Description \\
\hline $\begin{array}{l}\text { Decision to adapt to climate } \\
\text { change }\end{array}$ & Do you adapt to climate change & $\begin{array}{l}\text { Dummy, takes the value of } 1 \text { if YES } \\
\text { and } 0 \text { if NO }\end{array}$ \\
\hline Age & Age of selected farmers & Continuous \\
\hline Household size & Farmers family size & Continuous \\
\hline Farming experience & Years of farming experience & Continuous \\
\hline Years of education & Farmers years of education & Continuous \\
\hline Access to labour & Do you have access to labour & $\begin{array}{l}\text { Dummy, takes the value of } 1 \text { if YES } \\
\text { and } 0 \text { if NO }\end{array}$ \\
\hline Access to extension & Do you receive extension service & $\begin{array}{l}\text { Dummy, takes the value of } 1 \text { if YES } \\
\text { and } 0 \text { if NO }\end{array}$ \\
\hline Access to farm equipment & $\begin{array}{l}\text { Do you have access to requisite farm } \\
\text { equipment }\end{array}$ & $\begin{array}{l}\text { Dummy, takes the value of } 1 \text { if YES } \\
\text { and } 0 \text { if NO }\end{array}$ \\
\hline Access to pesticides & Do you have access to pesticides & $\begin{array}{l}\text { Dummy, takes the value of } 1 \text { if YES } \\
\text { and } 0 \text { if NO }\end{array}$ \\
\hline
\end{tabular}

Akaike Information Criteria (AIC) provided the basis for model selection (Akaike, 1973). AIC select the model that minimises the negative likelihood penalized by the number of parameters as specified in the model. It basically finds the best approximating model to the unknown true data generating process and its applications (Akaike, 1973; Acquah, 2011).

Table 2 - Variable description 


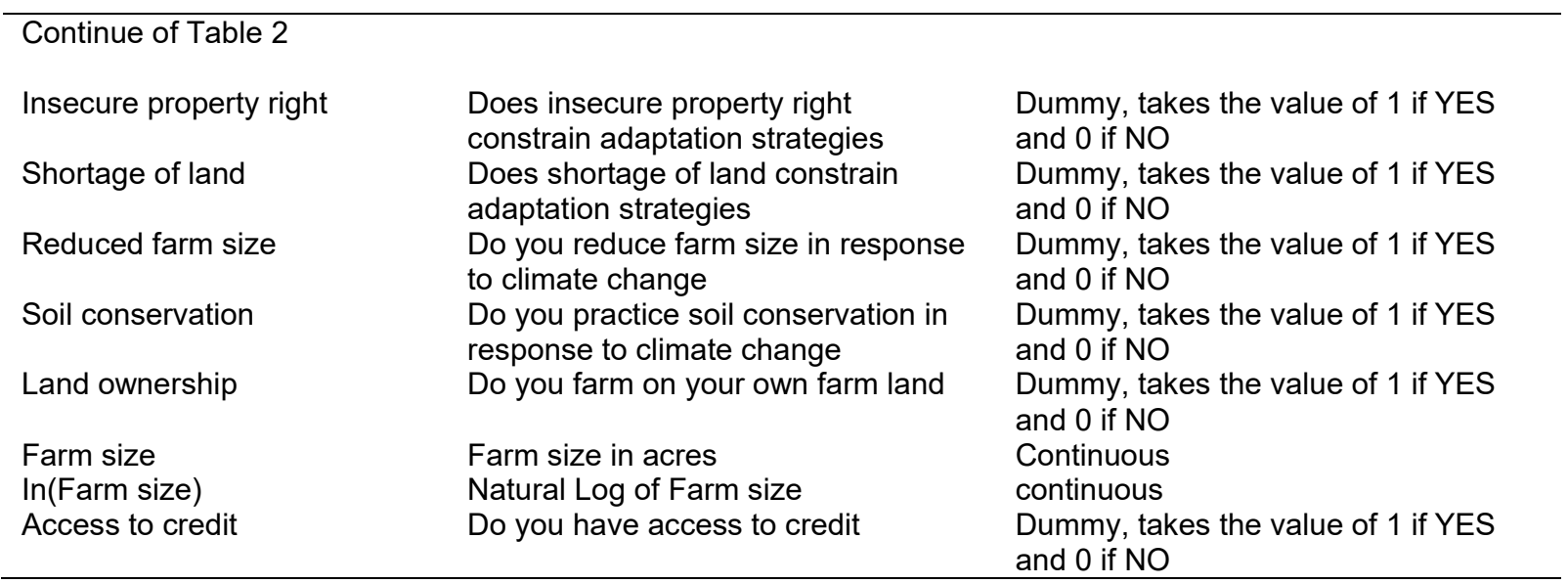

\section{RESULTS AND DISCUSSION}

Farmers in the Shama district have no doubt that climate is changing. The manifestations of climate as witness by farmers in the district are summarized in Figure 3. Farmers in the district perceived substantial decrease in rainfall, water levels in streams, vegetation cover, soil fertility, crop yields and wildlife. They have also noticed an increase in temperature. See Figures 1 and 2 . In response to the above mentioned changes, farmers adapt to climate change using farm level adaptation strategies.

Climate change adaptation strategies are crucial if the long term impacts on food production are to be minimised. Farmers were interviewed to know their choice of adaptation strategies in response to climate change. The results revealed that farmers use one or more methods of adaptation. Major adaptation strategies identified in response to climate change include changing planting dates, reduced farm size, crop diversification and soil conservation. Figure 4 summarizes the above mentioned findings. Nevertheless, there are barriers to farmers' adaptation strategies. The farmers identified eight barriers to adaptation strategies in the Shama district. These barriers are presented in Figure 5.

\section{Current Changes in rainfall}

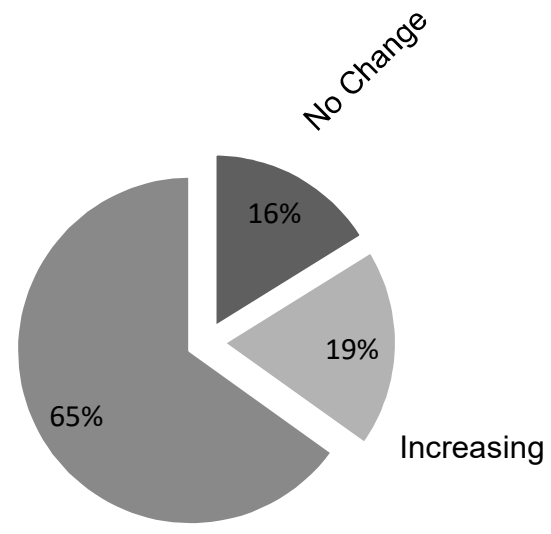

Decreasing

\section{Changes in rainfall ten years ago}

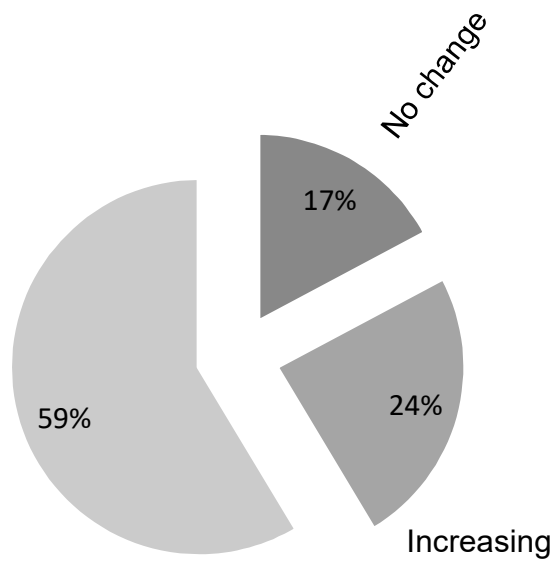

Decreasing

Figure 1 - Perceived changes in rainfall 
Current changes in temperature

$\mathrm{O}_{\mathrm{Co}_{\mathrm{s} / \mathrm{s}_{0}}}$

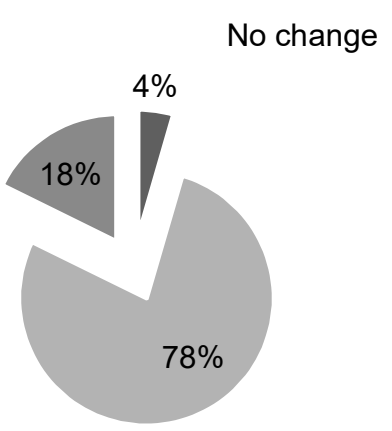

Increasing
Changes in temperature ten years ago
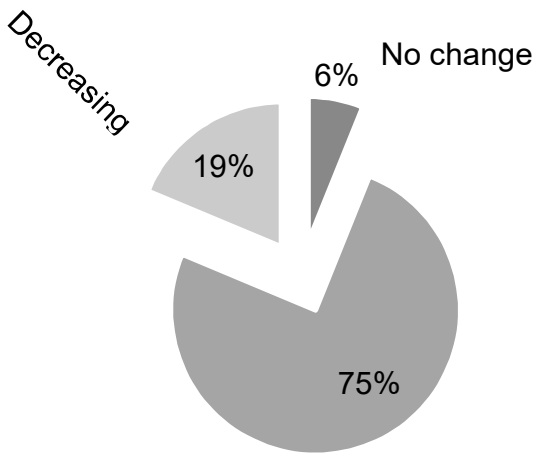

Increasing

Figure 2 - Perceived changes in temperature

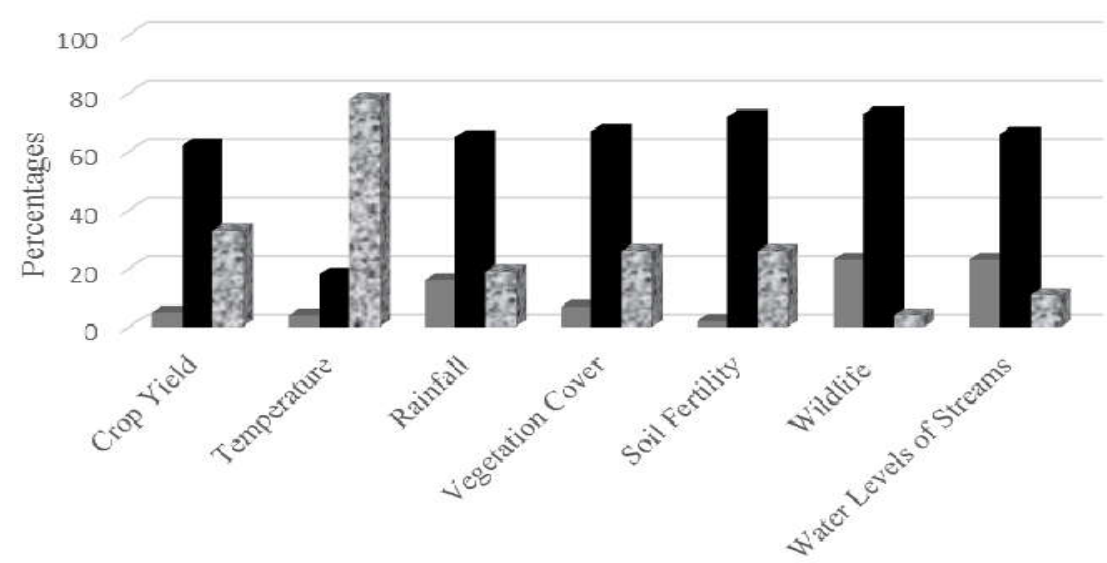

Indicators

No change Decreasing AIncreasing

Figure 3 - Manifestations of climate change
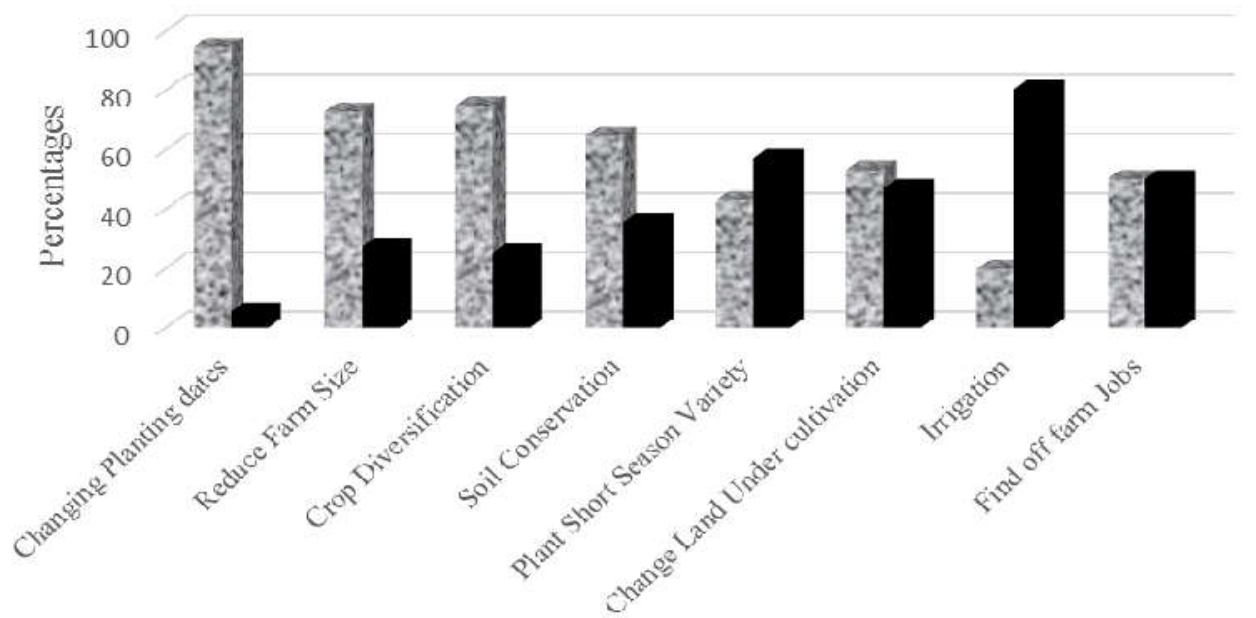

Adaptation Stratcgics

$$
\triangle \% \text { Yes } \quad \text { - } \% \text { No }
$$

Figure 4 - Adaptation Strategies in response to climate change 


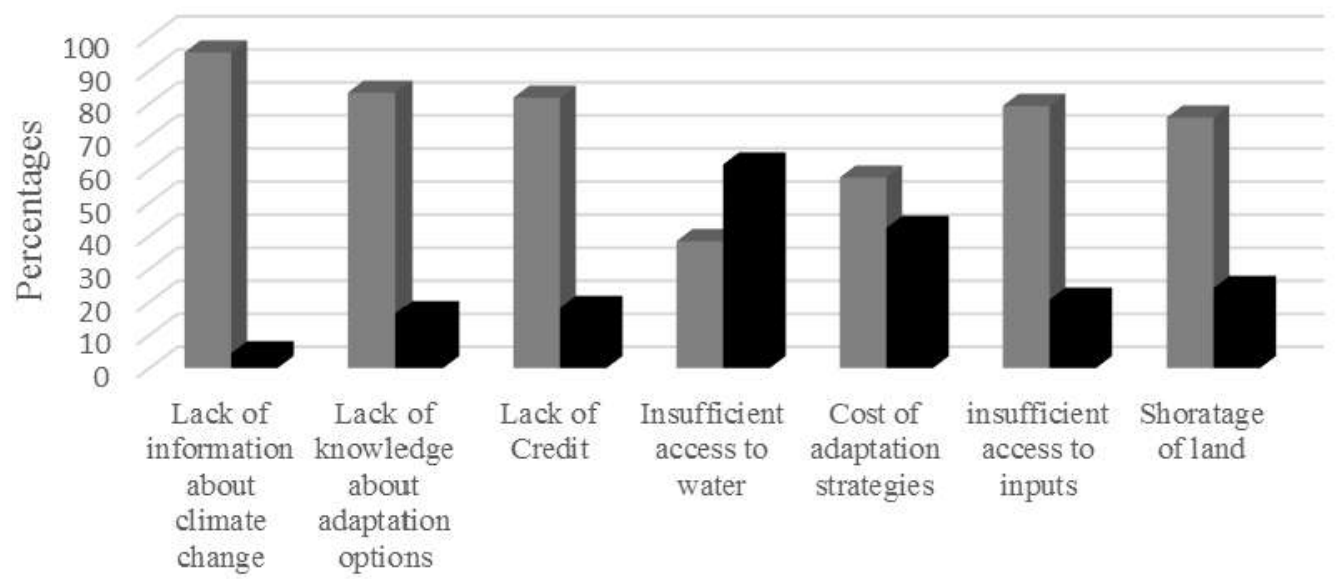

Barriers

- $\%$ Yes $\%$ No

Figure 5 - Barriers to adaptation strategies in the Shama district of Ghana

Binary Logistic Regression results. Table 3 summarizes the results from the binary logit analysis. The model specification with decision to adapt to climate change as a dependent variable and household size, years of education, years of farming experience, access to extension service, access to labour, and access to requisite farm equipment as the explanatory variables provided the best fit with AIC of 111.227. Evidence from the logit regression analysis finds household size, years of farming experience, and access to requisite farm equipment as significant predictors of farmers' decision to adapt to climate change.

A unit increase in access to requisite farm equipment increases the logit of the dependent variable, decision to adapt to climate change by 2.0842 holding all other variables in the model constant. On the other hand, increasing a farmer's household size by one person is $19.4 \%$ less likely to support the decision to adapt to climate change controlling for all other variables in the model. Similarly, one-year increase in farming experience means a farmer is 1.058 times more likely to support the decision to adapt to climate change holding all variables constant. The marginal effect of each predictor on the decision to adapt to climate change was estimated. For instance, a unit increase in access to requisite farm equipment increases the probability of a farmer adapting to climate change by $14.8 \%$. Meanwhile increasing a farmer's household size by one person decreases the probability of adapting to climate change by $1.5 \%$. Policy decisions on farm level adaption to climate change may focus on the above mentioned factors since they make significant contributions to farmers' decision to adapt to climate change.

The inadequate access to credit presents a major barrier to farmers' decision to adapt to climate change. It is therefore relevant to know the socio-economic characteristics of farmers that can influence their access to credit from banks and other financial institutions. The logit model specification with access to credit as the dependent variable and age, years of education, years of farming experience, access to labour, insecure property right, shortage of land, reduced farm size and soil conservation as regressors provided the best model fit with AIC of 172.25. See Table 4 for the results.

The results revealed that years of farming experience, soil conservation, insecure property right and shortage of land decrease farmers' likelihood of having access to credit. For instance, insecure property right is $59.4 \%$ less likely to help farmers gain access to credit from financial institutions controlling for all other variables. This aspect of the results meets expectations because financial institutions often require land or a fixed asset as collateral for agricultural loans. Therefore, a general decline in arable land available for production or an insecure property right may potentially decrease farmers' access to credit from banks or 
other financial institutions. Furthermore, the type of soil conservation mainly practiced by farmers in the district is basically allowing arable land to fallow for a few years. This practice tends to decrease farmers' land as a potential asset for agricultural loans.

On the other hand, age, years of education, access to labour and reduced farm size increases the likelihood of farmers gaining access to credit. For instance, farmers consciously reducing their farm size in response to climate change although arable land existed increases the likelihood of obtaining credit from financial institutions. A unit increase in the reduction of farm size in response to climate change increases the probability of obtaining access to credit by $22 \%$ controlling for all other variables in the model. One-year increase in farmers' age is 1.117 times more likely to increase access to credit controlling for all other variables in the model. Furthermore, one-unit increase in access to labour increases access to credit by 7.625 holding all other variables in the model constant.

Table 3 - Results from the binary logit model on farmers' decision to adapt to climate change

\begin{tabular}{lllllll}
\hline \multicolumn{7}{c}{ Dependent Variable: Decision to adapt to climate change } \\
\hline Independent variable & $\begin{array}{l}\text { Parameter } \\
\text { Estimate }\end{array}$ & $\begin{array}{l}\text { Standard } \\
\text { error }\end{array}$ & $\begin{array}{l}\text { Wald } \\
\text { Chi-Square }\end{array}$ & $\begin{array}{l}\text { Odds } \\
\text { Ratio }\end{array}$ & $\begin{array}{l}\text { Marginal } \\
\text { effect }\end{array}$ & Pr> ChiSq \\
& 2.9162 & 0.9232 & 9.9772 & - & - & 0.0016 \\
Intercept & -0.2155 & 0.1038 & 4.3130 & 0.806 & -0.0154 & 0.0378 \\
Household Size & 0.0561 & 0.0283 & 3.9148 & 1.058 & 0.0040 & 0.0479 \\
Farming Experience & -0.9583 & 0.5709 & 2.8178 & 0.384 & -0.0683 & 0.0932 \\
Access to extension & -0.9368 & 0.6180 & 2.2978 & 0.392 & -0.0668 & 0.1296 \\
Access to labor & 2.0842 & 0.5786 & 12.9744 & 8.038 & 0.1486 & 0.0003 \\
Access to farm equipment & & & & & & \\
AlC & 111.227 & & & & & \\
Sample size & 198 farmers & & & & & \\
Likelihood ratio test & Chi-Square: & 21.4089 & Pr>ChiSq & 0.0007 & & \\
\hline
\end{tabular}

Table 4 - Results from the binary logit model on access to farm credit

\begin{tabular}{lllllll}
\hline \multicolumn{7}{c}{ Dependent Variable: Access to Credit } \\
\hline Independent variable & $\begin{array}{l}\text { Parameter } \\
\text { Estimate }\end{array}$ & $\begin{array}{l}\text { Standard } \\
\text { error }\end{array}$ & $\begin{array}{l}\text { Wald } \\
\text { Chi-Square }\end{array}$ & $\begin{array}{l}\text { Odds } \\
\text { Ratio }\end{array}$ & $\begin{array}{l}\text { Marginal } \\
\text { effect }\end{array}$ & Pr> ChiSq \\
\hline Intercept & -5.9170 & 1.3489 & 19.2402 & - & - & $<0.0001$ \\
Age & 0.1109 & 0.0295 & 14.1235 & 1.117 & 0.0137 & 0.0002 \\
Years of education & 0.1324 & 0.0445 & 8.8692 & 1.142 & 0.0164 & 0.0029 \\
Farming Experience & -0.0824 & 0.0291 & 8.0095 & 0.921 & -0.0102 & 0.0047 \\
Access to labor & 2.0314 & 0.5571 & 13.2971 & 7.625 & 0.2518 & 0.0003 \\
Reduce farm size & 1.7800 & 0.5476 & 10.5681 & 5.930 & 0.2206 & 0.0012 \\
Soil conservation & -1.9082 & 0.5208 & 13.4240 & 0.148 & -0.2365 & 0.0002 \\
Insecure property right & -0.9012 & 0.4220 & 4.5600 & 0.406 & -0.1117 & 0.0327 \\
Shortage of land & -1.7660 & 0.5186 & 11.5970 & 0.171 & -0.2189 & 0.0007 \\
AlC & & & & & & \\
Sample size & 172.25144 & & & & & \\
Likelihood ratio test & 198 farmers & & & & & \\
\hline
\end{tabular}

Semi-log regression results. In response to the factors that influence farmers land in production, the ordinary least square regression model (with the logarithm of farm size as the dependent variable and farmers' socio-economic variables as predictors) was estimated. The results obtained from the regression analysis revealed age of respondents, farmers' household size, years of farming experience, farming on one's own farmland, access to pesticides and access to extension services as significant predictors of land in production.

On average, one-year increase in the age of a farmer decreases land in production by 1.7 percent holding all other variables in the model constant. The negative effect of age on the size of land in production meets research expectation. Farming in Africa and specifically the study area is largely own-labor intensive. Therefore, it is reasonable for an increase in age to negatively affect farm size especially in the absence of an outside farm labor sources. 
On the other hand, increasing farmers' household sizes by one person, increases land in production by 5.39 percent controlling for all other variables. This aspect of the results is theoretically correct because most farmers in the district tend to use their family as additional sources of farms labor. Likewise, a unit increase in access to extension services increase land in production by 0.47 controlling for all other variables in the model.

The assumptions underlying the Ordinary Least Squares estimation was tested to ensure that there are no violations and the predictability of the model is not impaired. Homoskedasticity which assumes that the residuals have equal variance was tested using both the White test and the Breusch-Pagan test. Generally, the null hypothesis of homoscedasticity is tested against the alternative of hetroskedasticity. The result showed no violation since $p$-values obtained from each test was larger than 0.05 and the null hypothesis of homoscedasticity is not rejected. Multicollinearity was not an issue by the variance inflation factor (VIF) results and the residuals were normally distributed. Table 5 presents results on the parameter estimates, hetroskedasticity, Variance Inflation Factor and normality test.

Table 5 - Results from the semi-log regression model on farmers' land in production

\begin{tabular}{|c|c|c|c|c|c|}
\hline \multicolumn{6}{|c|}{ Dependent Variable: log of Farm Size (in acres) } \\
\hline Independent variable & $\begin{array}{l}\text { Parameter } \\
\text { estimate }\end{array}$ & Standard error & $\begin{array}{l}\text { t-test } \\
\text { statistic }\end{array}$ & $\operatorname{Pr}>|t|$ & $\begin{array}{l}\text { Variance } \\
\text { inflation }\end{array}$ \\
\hline Intercept & 0.46678 & 0.20725 & 2.25 & 0.0254 & 0 \\
\hline Age & -0.01706 & 0.00590 & -2.89 & 0.0043 & 2.60196 \\
\hline Household size & 0.05396 & 0.01898 & 2.84 & 0.0050 & 1.30054 \\
\hline Farming experience & 0.03981 & 0.00582 & 6.84 & $<.0001$ & 2.30945 \\
\hline Own farmland & 0.44420 & 0.09767 & 4.55 & $<.0001$ & 1.14640 \\
\hline Access to Pesticides & 0.29148 & 0.10482 & 2.78 & 0.0060 & 1.24601 \\
\hline Access to extension & 0.47091 & 0.09900 & 4.76 & $<.0001$ & 1.21953 \\
\hline \multicolumn{6}{|c|}{ F Value $30.68 \mathrm{Pr}>\mathrm{F}<.0001$} \\
\hline Sample Size & 197 & & & & \\
\hline R-square & 0.4921 & & & & \\
\hline \multicolumn{6}{|c|}{ Shapiro-Wilk test Statistic 0.99114 p-value 0.2683} \\
\hline \multicolumn{6}{|c|}{ Kolmogorov-Smirnov Statistic $0.05452 p$-value $>0.1500$} \\
\hline \multicolumn{6}{|c|}{ Breusch-Pagan test Chi-Square 25.25 Pr>ChiSq 0.3924} \\
\hline
\end{tabular}

\section{CONCLUSION}

The results revealed several important policy conclusions:

Farmers in the Shama district believe climate is changing and this is evidence in their perceptions. Farm level adaptation strategies are used in response to climate change. However, the farmers in this area experience some challenges in adapting to climate change. Major barriers to farm level adaptation include lack of information about climate change, lack of knowledge about adaptation strategies and lack of access to credit.

When faced with the many uncertainties posed by climate change impacts, the capacity to access, use and disseminate relevant information becomes crucial for vulnerable communities in order to better cope with and adjust to new climatic conditions. Therefore, the knowledge and experiences of rural farmers should not be limited. More innovations such as educating farmers about the availability of new technology and how to use it, providing information on improved farm management techniques such as optimal farm input use, or providing forecast information about likely short- or longer-run shifts in climate should be made available to farmers.

Analysis on a farmer's lack of access to credit revealed that shortage of land, insecure property right and inadequate soil conservation practices reduce access to credit. Institutional factors such as Access to credit, Insecure Property Right and Information on climate change are key in alleviating the impact of climate change. Policy may focus on addressing issues of insecure property right as well as climate change mitigation policies such as tree planting to bring substantial land into production for increased agricultural productivity and farmer's access to agricultural loan. 


\section{ACKNOWLEDGEMENT}

The authors gratefully acknowledge financial assistance from Philanthropic Educational Organization - International Peace Scholarship (IPS) in support of Sarah Acquah's graduate studies.

\section{REFERENCES}

1. Acquah, H. (2011). Farmers' perception and adaptation to climate change: A willingness to pay analysis. Journal of Sustainable Development in Africa, 13(5).

2. Adger, W. N. (1999). Social vulnerability to climate change and extremes in coastal Vietnam. World Development, 27, 249-269.

3. Agresti, A. (1996). An introduction to categorical Data Analysis. Annual Review of Sociology (Vol. 22). http://doi.org/10.1198/jasa.2008.s251

4. Akaike, H. (1973). Information theory and an extensión of the maximum likelihood principle. International Symposium on Information Theory, (1973), 267-281. http://doi.org/10.1007/978-1-4612-1694-0

5. Christensen J.H, Hewitson B, Busuioc A, Chen A, Gao X, Held I, Jones R, Koli RK, Kwon WT, Laprise R, Rueda VM, Mearns L, Menéndez CG, Räisänen J, Rinke A, S. A. and W. P. (2007). Climate Change 2007: The Physical Science Basis. In Contribution of Working Group I to the fourth assessment report of the Intergovernmental Panel on Climate Change.

6. Dumenu, W. K. (2014). Climate change and rural communities in Ghana: Insight from social vulnerability assessment. In Fisrt National Forestry Conference, 16-8 September, 2014.

7. Ghana Statistical Service. (2014). Statistical Report 2014. Retrieved from www.statsghana.gov.gh

8. Masters, G., Baker, P. \&, \& Flood, J. (2010). Climate change and agricultural commodities. CABI Working Paper, 2.

9. Salvini, G., Ligtenberg, A., van Paassen, A., Bregt, A. K., Avitabile, V., \& Herold, M. (2016). REDD+ and climate smart agriculture in landscapes: A case study in Vietnam using companion modelling. Journal of Environmental Management, 172, 58-70.

10. Trenberth, K. E., Fasullo, J. T., \& Shepherd, T. G. (2015). Attribution of climate extreme events. Nature Climate Change, 5(August), 725-730. http://doi.org/10.1038/nclimate2657

11. United Nations Framework Convention on Climate Change. (2011). National Adaptation Strategy, Ghana. In Presentation on Ghana at the expert meeting on national adaptation plans. Don Chan Palace, Vientiane, LAOS: 15-17 September 2011. 